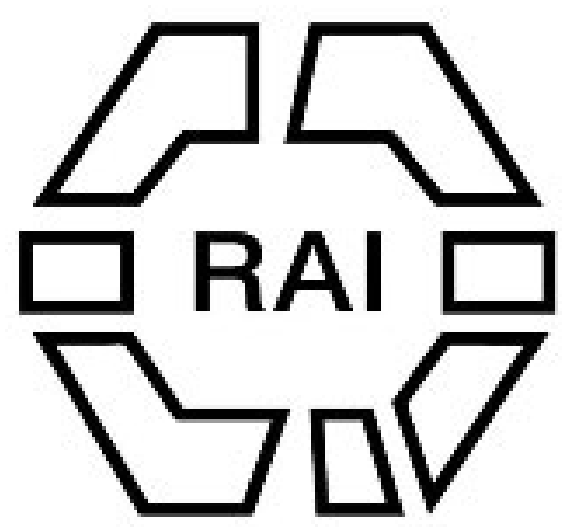

On the Prehistoric Interments of the Balzi Rossi Caves Near Mentone and Their Relation to the Neolithic Cave-Burials of the Finalese

Author(s): Arthur J. Evans

Source: The Journal of the Anthropological Institute of Great Britain and Ireland, Vol. 22 (1893), pp. 286-307

Published by: Royal Anthropological Institute of Great Britain and Ireland

Stable URL: http://www.jstor.org/stable/2842129

Accessed: $15 / 06 / 2014$ 10:48

Your use of the JSTOR archive indicates your acceptance of the Terms \& Conditions of Use, available at http://www.jstor.org/page/info/about/policies/terms.jsp

JSTOR is a not-for-profit service that helps scholars, researchers, and students discover, use, and build upon a wide range of content in a trusted digital archive. We use information technology and tools to increase productivity and facilitate new forms of scholarship. For more information about JSTOR, please contact support@jstor.org.

Royal Anthropological Institute of Great Britain and Ireland is collaborating with JSTOR to digitize, preserve and extend access to The Journal of the Anthropological Institute of Great Britain and Ireland. 
From the Secretary of State for the Colonies.-Despatches from His Honour the Administrator of British New Guinea. Nos. 22, 23, 24.

From the Trustees of the Melbodrne Public Library.-South Sea Languages. By the Rev. D. MacDonald. 2 vols. 8 vo. Melbourne, 1889-91. pp. 134; xxviii, 281.

From the Académie des Sciences de Cracotie.-Bulletin International. 1892. No. 8.

From the Geologists' Association.-Proceedings. Vol. xii, 9-10.

From the Detonshire Association fOR the Advancement of

Science, Literatere, and ARt.-Report and Transactions.

Vol. xxiv. The Devonshire Domesday. Part 9.

From the American Association for the Advancement of Science. -Proceedings. Vol. xl.

From the Essex Field Club.-The Essex Naturalist. Vol. vi, 10. From the Royar, United Service Institution.-Journal. No. 177. From the Australian Museum.-Records. Vol. iii, 1.

From the EdrToR.-Nature. Nos. 1203-1205.

— Science. Nos. 508-511.

- L'Anthropologie. T. iii, 4.

Revue Scientifique. T. 1, 20-23.

From the École D'Anthropologie de Paris.-Revue Mensuelle. $1892,11$.

From the Berliner Gesellschaft für Anthropologie, Ethrologie UND URGESCHICHTE.-Z Zeitschrift für Ethnologie. 1892. Heft 4.

From the Royal Astatic Societr, Cerlon Branch.-Journal. No. 39.

From the Royal Scottish Geographical Society.-The Scottish Geographical Magazine. Vol. viii, 12.

From the Societì Italiana di Antropologia, Etnologia, e Psicologia Comparata.-Archivio per l'Antropologia e la Etnologia. Vol. xxii, 2.

From the Sociedade de Geographia de Lisboa.-Boletim. 10A Serie, $12 ; 11_{\mathrm{A}}$ Serie, $1,2$.

From the Royal Geographical Society.-Proceedings. Vol. xiv, $11,12$.

From the Royal Society.-Proceedings. No. 316.

From the Society of ARTs.-Journal. Nos. 2086-2089.

From the Society of Biblical Archalology.-Proceedings. Vol. $x \nabla, 1$.

From the Niederiadusitzer Gesellschaft für Anthropologie und UrGeschichte.-Mittheilungen. Band ii, 6.

From the Société Impériale des Naturalistes de Moscou.Bulletin. 1892, 2.

From the Anthropological Soctety of Washington.-The American Anthropologist. Vol. v, 4 .

From the Polinesian Society.-Journal. Vol. i, 3.

Mr. A. J. Evans read a Paper on "A Prehistoric Interment in the Cave of Barma Grande, near Mentone." 
Mr. J. Alien Brown, Dr. Garson, and Dr. Trlor took part in the discussion, and the Author replied.

Dr. H. Colley March read a Paper on "Polynesian Mythography; a Symbolism of Origin and Descent."

\section{On the Prehistoric Interments of the Balzi Rossi Caves near Mentone and their relation to the NeOLITHIC CaVE-BURIALS of the Finalese. ${ }^{1}$}

By Arthur J. Evans, M.A., F.S.A.

ON February 7th, 1892, a fresh discovery of human skeletons associated with primitive implements and ornaments was made in one of the caves near Mentone that have already been the scene of more than one interesting discovery. The cave in which the present find was made bears the name of Barma Grande, and is one of a series of grottoes that honeycomb the sea-face of the promontory of Lower Cretaceous Limestone that rises just across the Italian frontier on the Ventimiglia side of Mentone, and which, from its red bastions, is locally known as Baoussé Roussé, in its Tuscan form as Balzi Rossi. It lies in the Commune of Grimaldi.

Earlier discoveries of human remains in these caves have already been described by M. Emile Rivière ${ }^{2}$ and others, and from the bones of extinct animals found in cave-earth in which the human interments occurred $M$. Rivière has not hesitated to refer them to the Palæolithic Age. The same view of these discoveries has been taken by Professor Issel of Genoa, who, however, in his recent book on Liguria ${ }^{3}$ uses the word Miolithic, intending to indicate a period between the pure Palæolithic and Neolithic times. But the evidence on which a Palæolithic antiquity was claimed for one of the earlier skeletons found, now in the Natural History Museum at Paris, has not by any means met with universal acceptance. ${ }^{4}$

1 An account of this find, incorporated, with additions and some slight rectifications, in the present, paper, was communicated by me in April, 1892, to the "Prähistorische Blatter" of Munich (1892, No. 3: "Entdeckung von drei menschlicherı Skeleten in die Höhle Barma Grande zwischen Mentone and Ventimiglia"). An excellent article on the same subject ("The Cave Men of Mentone") by Mr. A. Vaughan Jennings, F.L.S., F.G.S., to which I have had the advantage of referring in the course of this paper, appeared in "Natural Science" (June, 1892). To this must now be added another by Dr. Verneau in "Anthropologie," III (1892), p. 513, seqq.

2 "De L'Antiquité de l'homme dans les Alpes Maritimes." Paris, 1887.

3 "Liguria Geologica e Preistorica," vol. ii, p. 265.

4 Eg. Boyd Dawkins: "Cave Hunting," p. 258; and $c f$. "Early Man in Britain," p. 229. G. de Mortillet: "Arch. préistorique," p. 390. Pengelly, 
Of these earlier discoveries the most important, at any rate the most completely described, was that made by $\mathrm{M}$. Rivière in 1872 in the neighbouring Barma dou Cavillou. ${ }^{1}$ Here at a depth of 6.55 metres beneath the surface of the cave-earth, which consisted of ashes, with animal bones and small instruments of bone and flint, he discovered a human skeleton. But, as bearing on the conclusions as to the date of the cave, it is to be noted that no stalagmitic layer was encountered.

The skeleton lay on its left side in the attitude of sleep. A stone lay beneath its head and another behind the loins. An ornament composed of bored shells-which may recall the trochus-studded nets still worn by Venetian peasants-was found adhering to the skull, their adherence being due to a ferruginous substance, fragments of which lay near, and which gave a ruddy colour to the whole. Evidently this ochreous substance had been used by the departed in his life-time to paint his face and body, and the whole character of the deposit clearly points to careful interment. From the discovery of bones of extinct animals mixed with the ashes in the overlying stratum, $\mathbf{M}$. Rivière concluded nevertheless that the skeleton was palæolithic.'

But M. Rivière wholly omitted from his reports on the cave and its contents the very important results already obtained by Mr. Moggridge from the same grotto. ${ }^{3} \quad$ Mr. Moggridge made a section of the Barma dou Cavillou when the cave was nearly intact, missing the skeleton afterwards brought to light by no more than 2 feet. He discovered "five floors formed in the earth by long continued trampling," containing near the centre in each case traces of a hearth, and, around, flint flakes and axes,

“Trans. of Devonshire Ass.," 1873, p. 315, seqq., while admitting difficulties, was inclined to accept the Palæolithic Age of the skeleton found in the Barma dou Cavillou in 1872 .

'Émile Rivière: "De l'Antiquité de l'homme dans les Alpes Maritimes," Paris, 1887, p. 127, seqq. Cf. W. Pengelly: "The Cave Man of Mentone," "Trans. of Devonshire Ass.," 1873, p. 293, seqq.

2 "Découverte d'une squelette humaine de l'époque paléolithique dans les cavernes de Baoussé Roussé," 1873, and $c f$. "De l'Ântiquité de l'homme dans les Alpes Maritimes," p. 127, segg. Amongst the bones discovered were represented Ursus spelæus (numerous teeth, a few bones), Ursus arctos, Canis lupus, Canis vulpes, Mustela vulgaris, Hyæna spelæa, Felis antiqua, Felis spelæa, Felis lynx, Felis catus, Arctomys primigenia, Mus arvalis, M. muscardinus, Lepus cuniculus ; Rhinoceros tichorinus, Equus Caballus, Sus scrofa fossilis, Bos primigenius, Cervus alces, Cervus elaphus, Cervus Canadensis, Capra primigenia. Amongst the shells, the Oceanic and non-Mediterranean forms Purpura lapillus and Littorina littorea occurred; also Pecten maximus and Cassis saturon, which are common Atlantic forms, though very rare in the Mediterranean. Some fossil forms such as Nummulites perforata were found. On the mammalian remains of this Cave see Boyd Dawkins, "Cave Hunting," p. 375, note.

3 "Brit. Assoc. Rep.", 1871, p. 156. Cf. Boyd Dawkins: "Cave Hunting," p. 374. See too Pengelly : "Trans. of Devonshire Ass.," 1873, p. 296 seqq., and p. 305 , note. 
hammer-stones, and bones of animals. "The bones were those of animals still existing." This evidence points clearly to the conclusion that the cave was inhabited in neolithic times. As a matter of fact, in his first account of his excavations M. Rivière described a pottery whorl as having occurred in a superficial stratum, ${ }^{1}$ and an implement of jade was also discovered. It is further to be noted that amongst the objects found in a surface layer of the innermost part of M. Rivière's "Third Cave" is a part of a polished stone axe showing traces of fire. ${ }^{2}$

The annexed diagram (Fig. 1) will give an idea of the general conformation of the cave or cleft known as the Barma Grande in which the most recent discoveries have been made. From the data that I was able to gather on the spot from quarrymen who at one time or another had taken part in its excavation, the original floor of the cave, at its mouth, over the spot, that is, where the skeletons were found, was 7.50 metres above shelaten where the stratum in which they lie. But this depth only includes what has been artificially removed from the cave. There are reasons for believing that the deposit had originally been somewhat higher but that the original level of the floor had been previously

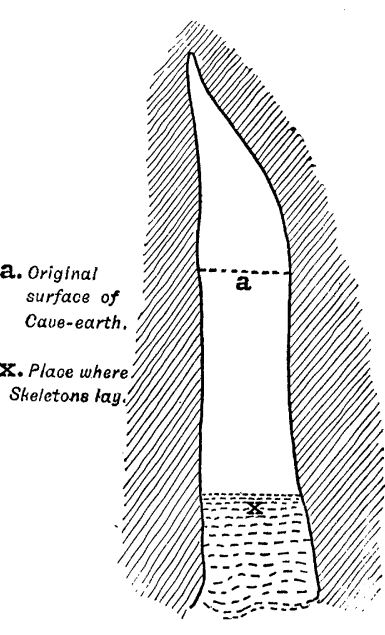

FIG. 1. lowered by natural agencies. ${ }^{3}$

As early as $18 \check{8} 8 \mathrm{M}$. Forel, a Swiss geologist, ${ }^{4}$ had obtained from the superficial layer of the cave, half a yard thick, various bones and implements. The animal remains are described as those of the stag, roe, sheep, antelope (?), aurochs, horse, boar, wolf, fox, cat, rabbit, cachalot (?), and various shells (dentalium, patella, pecten, and pectunculus). Amongst the implements are

${ }^{1}$ In his revised account of the find, however ("De l'Antiquité de l'homme, \&c.." p. 164), M. Rivière reduces this to a flat disk of dark brown stone.

2 Rivière : op. cit., Pl. IX, 13. In his account of Cave 3, M. Rivière omits all mention of this discovery. It is difficult for the reader to remedy this omission for the book has no index, and the provenience of the objects in the plates is in most cases not given.

${ }^{3} C f$. A. V. Jennings : op. cit., 272, who cites M. Forel for the fact that as early as 1858-before the excavations had begun-the floor had been lowered by natural agencies "as shown by ossiferous incrustations clinging to the walls." Professor Issel considers that the original floor was 11 metres above the skeletons.

${ }^{4}$ See his "Notice sur les Instruments en Silex et les Ossements trourés dans les Cavernes à Menton," 1860. 
mentioned arrow heads, fish-hooks, spear heads, and short rough flint knives.

Between 1866 and 1886 M. Rivière,Professor Léone Orsini and others undertook a systematic excavation of the cave, and the whole contents of the outer part were eventually cleared out to about $1 \frac{1}{2}$ metres above the spot where the later discovery of skeletons were made. Remains of various extinct animals were found including most of the species found in the other caves. ${ }^{1}$ The most important discovery was due, however, to non-scientific hands. In 1884 Louis Julien, the foreman of the men employed in quarrying the cliff, who had taken up the work of excavation, unearthed, at a depth of 8.40 metres, $^{2}$ a more or less perfect skeleton. It is described as having had a large flake of flint at the top of the head, and two others at the shoulders "like epaulettes." The skull was coated with a red ochreous substance. Above was a layer of coal and ashes amongst which were the teeth of ruminants, ox, deer, and goat, and small flakes. The skeleton lay on its back between the cave wall and a large stone, with the head towards the mouth of the cave. The skull is now in the Mentone Museum.

It is to be observed, however, that in this case, as in the lower strata of the Barma dou Cavillou, no pottery was discovered. The cave-earth and the remains in it lay in a confused mass without regular stratification, and here again no layers of stalagmite occurred.

The present discovery, was made near the mouth of the cave and close to the spot where the skeleton of 1884 had been unearthed.

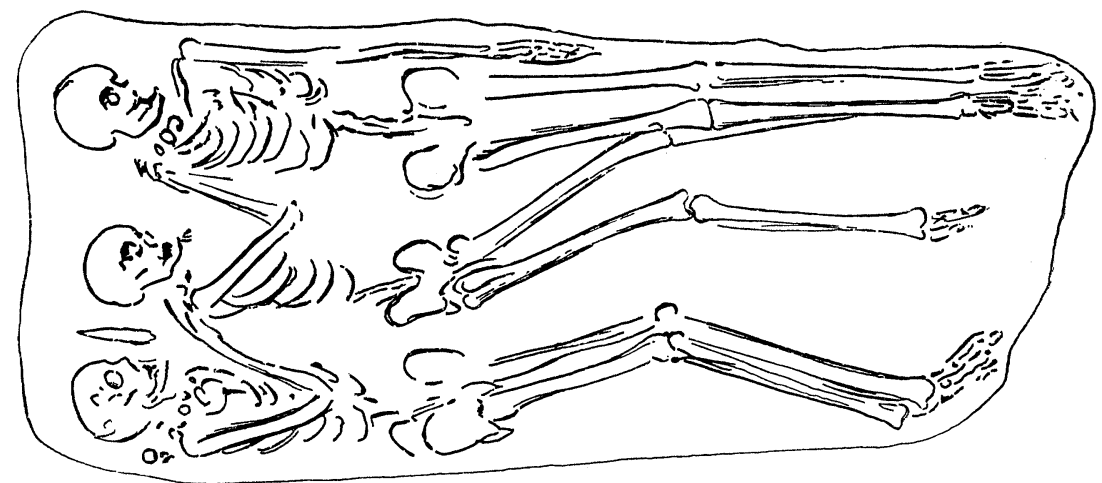

FIG. 2.

1 M. Rivière does not give a more exact account. Incidentally he mentions a bone of Ursus spelæus worked mito a punch.

2 See letter of Mr. Wilson, U.S. Consul at Nice, in "L'Homme," 1884, p. 186 : the skull is reproduced by M. Rivière, op. cit., p. 197. The cephalic index was $73 \cdot 0$, but complete measurements could not be taken. 
Unfortunately, as in the former case, it was not made by a scientific excavator but by men engaged in quarrying the limestone cliff. I visited the spot shortly afterwards on more than one occasion, but the ornaments and implements had been removed by the owner of the quarry to his house, and there was some difficulty in ascertaining the exact position in which the several relics were discovered.

The subjoined sketch (Fig. 2) will give a fair notion of the position in which the bodies were found. They lay across the present mouth of the cave with their heads to the east. The outermost skeleton was that of a man apparently well on in life. Unfortunately the skull was broken with a blow of a pick at the moment of discovery, and the length of the skeleton can therefore be only approximately given. From his heel to his shoulder he measured 1.85 metres, so that he was probably at least as tall as the taller of the three adult skeletons found in 1872-1873, which reached the length, according to M. Rivière, of 2 metres. This gigantic frame was somewhat turned to the left, but it lay more on its back than the other two. By his left hand, laid close to his femur, lay a long flint knife (Fig. 3). About the neck and on the skull were remains of ornaments of teeth and bone, fish vertebræ and pierced shells, among them many nassa neritea, and on the legs a little below the top of the tibias were two Cypræas. ${ }^{1}$

Immediately behind this lay a skeleton, recognised by Dr. Verneau ${ }^{2}$ as that of a woman. It rested on the left side with the knees slightly drawn up, and its right hand almost resting on the giant's shoul-

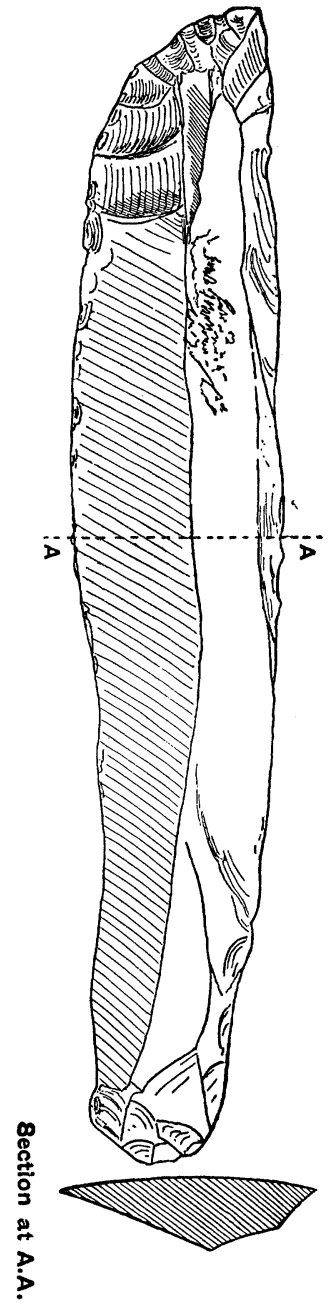
der. It is said to have held another flint FIG. 3.-FLINT KNIFE Foond knife. $^{3}$ This female skeleton was not so wIтH FIRST skeLeton. richly decked with ornaments as the other $\frac{1}{2}$ linear. $(23 \times 5 \mathrm{~cm}$.) two, the bone and tooth pendants being wanting in this case

1 I take this last statement from M. Rivière's short notice of the find in the Compte-rendu of the Académie des Sciences, of March 7, 1892.

2 "Anthropologie," III, 527. $\quad{ }^{3}$ A. V. Jennings, op. cit., p. 274. 
The third skeleton, of a youth, lay in much the same attitude as the second, with its right hand raised as if to be laid on the shoulder of the individual in front of it. Under or near its head a third flint knife was discovered (Fig. 4). Both
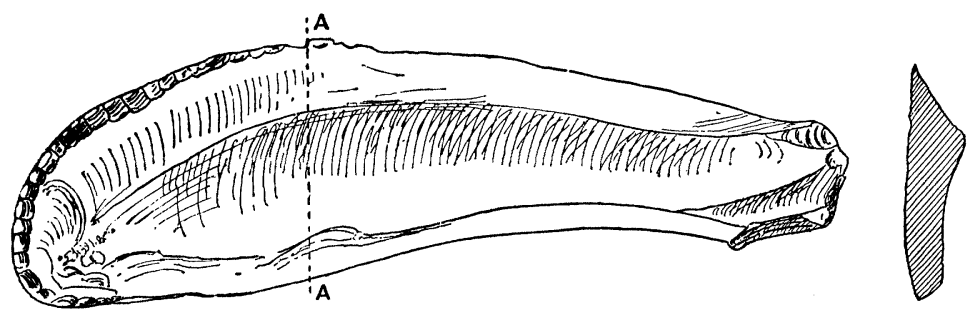

Section at A.A.

FIG. 4.-FLINT KNIFE FOUND WITH THIRD SKELETON. $\frac{1}{2}$ linear.

(Size, $17 \times 5 \mathrm{~cm}$.)

the two inner skeletons though of tall stature were distinctly smaller than the first discovered.

From the position in which the bodies lay it seems natural to conclude that the two smaller individuals here interred were in a position of dependence on the old giant. Amongst the objects found, chiefly, as far as I could gather, about the heads and necks of the skeletons, were remains of necklaces or head ornaments of shell and bone, amongst which may be mentioned bored shells, fish vertebræ, and teeth-apparently canines of deer -which had been much rubbed down and in some cases adorned with incised lines and nicks (Fig. 5). Of the bone ornaments dis-
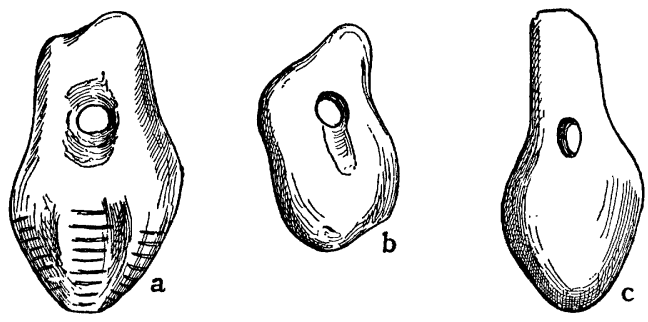

FIG. 5.-DEER'S-TOOTH PENDANTS.

covered, the most remarkable were some curious objects like double eggs or acorns connected by a common stem to which I shall return. These, too, were incised in a similar manner. Amongst the bored shells found I was shown specimens of small Cypræa, ${ }^{1}$ Cerithium, and a kind of Trochus, and a quantity of

${ }^{1}$ Identified by Mr. A. V. Jennings (op. cit., p. 276), with Cypræa millepunctata, an Atlantic species. 
Nassa neritea, ${ }^{1}$ the same shell that formed the head ornament of the skeleton excavated by $M$. Rivière in the Barma dou Cavillou. This correspondence is of great importance as showing that both interments belong to the same race and time. It is the more to be regretted that on ny second visit to the cave and its owner, who professed to keep the smaller relics found at his house, all these and several other objects had disappeared. The owner himself had made the discovery no small source of gain by charging visitors a fee of a franc apiece. In return for this, however, he did practically nothing to protect the skeletons, which in a few weeks' time were so trodden under foot as to be almost past recognition.

Another interesting correspondence between the present discovery and that of the Barma dou Cavillou was the presence, in the earth about the skeletons, of lumps of a ferruginous substance, which in this, as in the other cave, had partly stained the bones. There can be no doubt that this had been placed with the departed that he might have the wherewithal to paint his face and body for entry into the spirit world.

On the osteological characteristics of the skeletons I cannot speak as an expert. They have, however, been examined by competent authorities, whose accounts in the main agree. The skulls were decidedly dolichocephalic. The large skull has prominent supra-orbital ridges, the smaller skull has these prominences less marked and is narrower across the frontal bones, but, still, stronger, thicker, and more definitely ridged than the Neclithic skulls of the Finalese. Professor Issel, M. Rivière, Mr. A. V. Jennings, ${ }^{2}$ and more recently Dr. Verneau ${ }^{3}$ have been independentlyled to compare the Cro-Magnon skulls-M. Rivière especially laying stress on the curious rectangular orbits. Professor Issel, in a communication read before the Natural History

1 This observation is corroborated by M. Rivière, who also saw these shells, and by Dr. Verneau, "Anthropologie," III, 528.

${ }^{2}$ Mr. Jennings remarks, op. cit., 274, "As regards the skulls, . . . the first is of a size proportionate to the skeleton, and enough remains to show some general characters, though the left side, the jaw, and the basis cranii are wanting. The maximum length is $21 \mathrm{~cm}$., and the greatest width in the parietal region is $15 \mathrm{~cm}$. The cephalic indices are therefore 71.5 and 66.5 , the former very near that of the 1884 skull determined by Mr. Wilson ("Brit. Ass. Rep.,"1885, p.1218), as 71.35, and near those of Cro-Magnon. The craniofacial angle is not easy to determine, but it seems to be approximately $90^{\circ}$. The larger skull is higher in the parietal region, and projects to a remarkable extent above the occipital region, so much so that it is perhaps abnormal. The smaller skull is lighest in the posterior parietal region."

3 Dr. Verneau has restored what remained of the middle skull. He establishes the general resemblance of the Barma Grande skulls to those of Cro-Magnon, but observes that the forehead in this case is somewhat shorter and the skull higher-c" mais malgré tout, il se rapproche tellement, par le reste, du type de la Vézère, dont il exagère même certains traits, qu'il me semble impossible de l'en isoler," op. cit., p. 538. 
Society of Genoa of April 4, 1892, which I had the advantage of hearing, while in favour of the Palæolithic date of the skeletons, yet came to the conclusion that though the bones were thicker, the crania and skeletons, on the whole, presented the same racial characteristics as the undoubtedly Neolithic skeletons of the caves of Finale, further along the Ligurian Coast. Speaking as a non-expert I can only say that my own impression strongly agrees with this, and that the Mentone skeletons represent the same race as those of Finale, in a somewhat more primitive stage.

In view of the strong opinions that have been expressed as to the Palæolithic age of this and the other similar interments in the caves of Balzi Rossi, the following considerations will not be out of place:-

The great depth at which the skeletons were found both in the present instance and in the other allied discoveries, the undoubted fact that bones of extinct animals were found in the cave-earth above the level of the skeletons, and the absence, except in the case of a more or less superficial find, of polished stone implements, are all facts which give a primâ facie probability to the view that we have here to deal with remains of Palæolithic age. Another very remarkable phenomenon which distinguishes this whole group of discoveries from all hitherto known Neolithic interments is the absence of pottery. In the vast mass of deposit extracted by $M$. Rivière to a (iepth of 6.55 metres from the Barma dou Cavillou no pottery was found, nor was any noticed by Mr. Moggridge and other explorers. And this evidence becomes the more significant when it is added that in the still larger cave, the Barma Grande-with which we are dealing, in a still greater depth of deposit, no single fragment of pottery has been discovered. I myself on two different occasions have spent a considerable time hunting over the heaps of cave-earth turned out from above and around the skeletons, but was unable to find the smallest particles of earthenware.

This total absence of pottery from the present deposits becomes, moreover, still more remarkable when they are brought into comparison with the Neolithic interments of the caves of the Finale district, on the same Ligurian coast, between Albenga and Savona. In this case the deposits are in all cases associated with pottery, and the earth of these caves is full of sherds to a depth, in some cases, of 9 metres. The bones of domestic animals, moreover, are there abundant. In the Balzi Rossi group these too seem to be conspicuous by their absence.

From all this we may venture to arrive at one safe deduction. 
The interments of the Barma Grande, the Barma dou Cavillou and the other grottoes of the Balzi Rossi Cliffs belong to an earlier period than the Neolithic stratum so well represented in the Finalese. All this is in perfect keeping with the osteological evidence referred to above.

But are we therefore to conclude that the Balzi Rossi remains are of Palæolithic date?

It seems to me that there are other circumstances to be considered in connexion with these latter finds, which do not admit of such a conclusion-unless, indeed, the word "Palæolithic" is to be given a sense different from its usual acceptation.

When we come to examine the views as to the extreme antiquity of the instrurnents, such as $M$. Rivière has not hesitated to put forward in the most unqualified manner, we find, in fact, a curious illustration of the danger of proving too much. The skeletons lie in all cases beneath a vast mass of cave-earth in which the remains of extinct animals are undoubtedly associated with implements of flint and bone that may justly be regarded as the work of Palæolithic man. Therefore we are told the interments themselves must belong to the same age. Long flint knives such as those discovered, may, it is true, find parallels in some of the later Palæolithic caves such as that of La Madeleine, though like implements were also in common use in Neolithic times. But the argument invoked by M. Rivière leads us to consequences far beyond this. In the cave-earth of the overlying stratum implements occurred not only of types characteristic of the Magdalenian group, of Solutré, and of Laugerie Haute and Basse, but included quartzite and other forms peculiar to the still earlier art of Le Moustier. ${ }^{1}$ In the same way the bones of extinct animals found lead us on this showing to the conclusion that the "Man of Mentone" dated back to the days of the earliest group of pleistocene mammals.

The very fact that these different forms are mixed up together in the overlying cave-earth points clearly to partial or general disturbance. In the Barma dou Cavillou, moreover, our surprise at the great depth at which the interment occurred is considerably diminished when we find from Mr. Moggridge's observations that there had been six different floors of occupation dating from a period when the fauna was apparently confined to existing species. In the case of the Barma Grande, moreover, there is, as we have seen, distinct evidence that the floor level had once been higher and had subsequently been lowered by natural processes of denudation. But this raising

1 See Cazalis de Fondouce and Cartailhac, "Matériaux, \&c.," 1873, p. 133; 1)e Mortillet: "Arch. préistorique," p. 190. Quartzite implements of the Moustier type also occur in the grottoes of the Finalmarina district, notably the Arma delle Fate, associated with bones of Ursus spelæus. 
or lowering of the floor level by natural causes may have been carried on to a far greater extent than is now traceable. The jumble of bones and implements of different ages, the unstratified character of parts of the cave contents still visible-may it not at least be partly due to the past influence of flood-waters bringing down debris from interior cavities of the rock?

Making however every allowance for the operation of such causes the great depth at which these interments were found is still a phenomenon which must be taken into very serious account. It is moreover the more striking when we contrast it with the comparatively superficial character of the Neolithic graves in the caverns of the Finale district. In that case the average depth at which the skeletons lay was not more than about 50 centimetres, and though in places, owing to the accumulation of debris, it was as much as 2 metres $^{1}$ even this represents barely a quarter of the depth at which the Balzi Rossi deposits lay. The absence of pottery in this whole groul of caves, of polished implements, of the bones of domesticated animals, all this, as already pointed out, shows that the men buried there were living in a distinctly more primitive stage of culture than the Neolithic folk of the Finalese. Yet the Neolithic deposits of Finale which give place by insensible gradations to those of the early metal age and to forms akin to those of the Terremare of the other side of the Apennines, must themselves date back well beyond the thirl Millennium before our era.

The race of Balzi Rossi, then, must be fairly reckoned to be earlier than these, and if the ratio of the overlying deposit is to count for anything may precede them by thousands of years.

But granting this we must not shut our eyes to the fact that the interments of the Barma Grande and the Barma dou Cavillou present us with a cult of the dead, and, as I hope to show, with certain forms of ornaments and implements which find their nearest parallels rather among Neolithic than even the latest Palæolithic remains. Nor must it be forgotten that no bones of extinct animals have been in any case found in direct association with this group of skeletons. Several cases full of bones, found in the immediate neighbourhood of the skeletons, have now, in fact, been examined by Messieurs $H$. Filhol and M. Boule ${ }^{2}$ and proved to belong to the following animals:Fox, Horse, Wild Boar, Bison Europceus, Red and Roe Deer, Ibex, and an uncertain ruminant. It will be seen that not a single characteristic Quaternary animal occurs in the list. It is

1 See A. Issel, "Nuove ricerche sulle Caverne ossifere della Liguria" (Rome, 1888).

2 "Anthropologie," III, 532. 
to be observed moreover that the mere fact that these were interments, implying as it does previous excavation, makes the appearance of Pleistocene remains, and even Palæolithic implements at higher levels in the cave earth, of no value for determining the age of the skeletons.

The careful laying out of the dead in the attitude of sleep with his flint knife in his hand, his necklace and head ornaments, and the ochre beside him wherewith to paint his face and body in the other world-all this shows a development in religious custom which has hitherto in no single wellauthenticated instance been carried back to Palæolithic times. It is characteristically " Neolithic." We may go further and say that the special forms of sepulture discovered here fit on in a suggestive way to the burial rites still practised at a later date on this same coast by the Neolithic people of the Finalese. There too we find the body laid out in the same attitude of sleep, with the legs partially drawn up, an attitude which, as distinguished from the still more contracted posture of the Northern races in primæval times, we may perhaps venture to regard as characteristic of a less severe climate, and the less habitual necessity for drawing up the legs under the shelter of whatever served them as a mantle. There too we find the same bored shells and teeth hung round the neck, and the same ferruginous substance laid beside the departed to deck his person in the Spirit World; there too flint and bone objects (some of these latter of very similar forms) were placed ready to his hand. In the caves of Balzi Rossi however the skeletons were at most propped up or pillowed by large stones; in the Finale interments, such as those of the grotto of the Arene Candide we find in the case of the adults, stones placed round and over the skeletons so as to form a rude cist, though the children were still simply buried in the cave-earth. In these later interments moreover the polished axes and pottery placed beside the dead as well as the remains of domesticated animals attest the higher stage of culture amidst which they had lived. Still the points of similarity in the sepulchral rites practised in both groups are unmistakeable. And in view of these points of resemblance the conclusion arrived at by Professor Issel, that the Balzi Rossi skeletons, in spite of some more primitive characteristics, belong essentially to the same race as the skeletons of Finalmarina, gains additional force.

The bone implements supply us with some fresh points of relationship. The bored pendants, formed of canines of deer much worn down, found with the skeletons both in the Barma Grande and the Barma dou Cavillou are identical even to their notched decorations with ornaments of the same kind found by 
Professor Issel ${ }^{1}$ in the Caverna delle Arene Candide near Finalmarina (see Fig. 5) associated with undoubtedly Neolithic remains. Identical pendants have also been found in the Neolithic deposit of the Grotta di Sant' Elia in Sardinia. ${ }^{2}$ It is to be observed that very similar deer's tooth ornaments, though without the notches, were found in the caves of La Madeleine, Laugerie Basse and Les Eyzies, ${ }^{3}$ where they are ascribed to the Reindeer Period. A stumpy bone punch also found near the Barma Grande skeletons, in the possession of Mr. A. V. Jennings, is of the same type as a bone implement from the excavations of the Neolithic deposit in the grotto of the Arene Candide. ${ }^{4}$ Another very close parallel is afforded by the cusped bone instrument represented in Fig. 6 which the Rev. J. E. Somer-

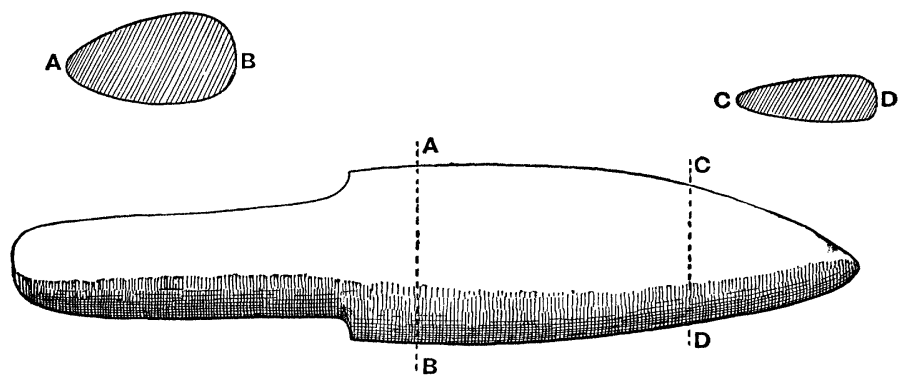

FIG. 6. -BONE ARROW-HEAD.

ville of Mentone obtained from the neighbourhood of one of the last discovered skeletons of the Barma Grande. Though blunter and thicker, it greatly resembles some of the bone heads described as "cuspidi di freccia ad alette" from the Neolithic burial place in the Arene Candide cave. ${ }^{5}$

Of all the bone objects, however, discovered with the present interments the most interesting are those already referred to as resembling two small eggs, or acorns, with their big ends united with a connecting stem. The bossy part of these ornaments was decorated with rows of parallel lines running up the sides like the rungs of so many ladders (Fig. $7 a$ and $b$ ). Seven or eight of these are said to have occurred in all, ${ }^{6}$ but, like other

1 "Scavi recenti nella Caverna della Arene Candide," Bull. di Paletn. it. Ann xii, Tav. iv, Figs. 9, 10. One is of shell.

2 In the Museo Kircheriano at Rome. They were kindly pointed out to me by Ispettore G.-A. Colini.

3 "Reliquiæ Aquitanicæ," B. Pl. V. 11, 12, 13, and p. 47, where they are referred to Red Deer ("Cervus elaphus").

${ }^{4}$ Issel, op cit., Tav. IV. 2 cf. Tav. VI. 6.

5 Op. cit., Tav. IV. 3 ; Tav. V. 7, 8.

6 I only saw three, and Mr. Jennings (op. cit. 276) the same number. He 
relics found, most of them have since disappeared. The shape of different specimens varied slightly, some being more elongated than others.
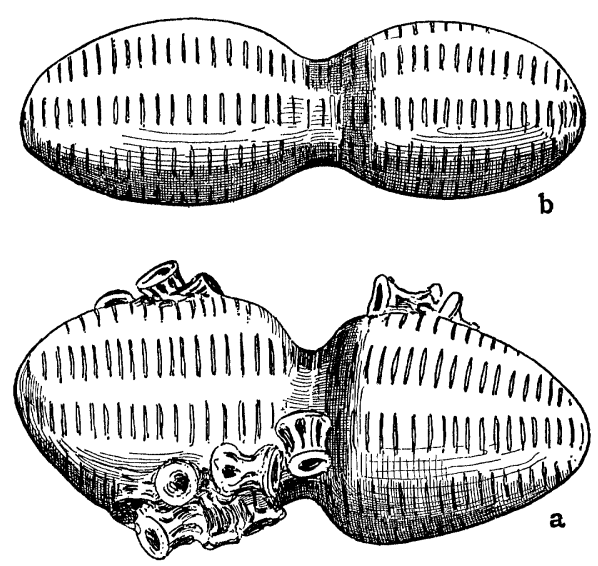

FIG. 7.-BONE ORNAMENTS.

(a) with fish-vertebræ adhering.

But what at once struck me on seeing these objects was the striking resemblance they presented to certain amber ornaments discovered with early Neolithic skeletons in the galleried tombs of Scandinavia and North Germany. In a communication to the Prähistorische Blätter, of Munich, on the subject of the present discovery, I have already called attention to this remarkable parallelism, and this view has since received a favourable reception in the North. My friend, Dr. Sven Söderberg, Director of the Museum of Lund, has kindly sketched for me some examples in that collection, which are here figured for the sake of comparison (Fig. 8). These doublebossed objects of amber are in Scandinavia generally known as " hammer-shaped" beads, ${ }^{2}$ and from their supposed resemblance to the stone-hammers of the saine period, have been by many supposed to have been worn as amulets. It is, however, noteworthy that the type which presents the greatest resemblance

describes them as having been found lying on the forehead of the skeletons. It is possible, as M. Rivière has suggested, that they are of stagshorn.

1 Dr. Söderberg writes "Die Zuzammenstellung von den Knochenperlen mit den scandinavischen Bernsteinperlen mit Keulenform ist 'quite striking' und die Ähnlichkeit kann unmöglich zufällig sein. Ich bin sicher dass der Fund von solchen Perlen in Italien ein grosses Aufsehen in der gelehrten Welt erwecken wird."

2 See on these especially Carl Neergaard, "Ravsmykkerne i Steenalderen" (Aarböger for Nordisk Oldkyndighed, 1888, p. 281, seqq.). Mesdorf, "Vorgeschichtliche Alterthümer aus Schles wig-Holstein," Fig. 117. 
to the Scandinavian stone-hammers ${ }^{1}$ is of later date than the others, and does not seem to occur in the chambered barrows
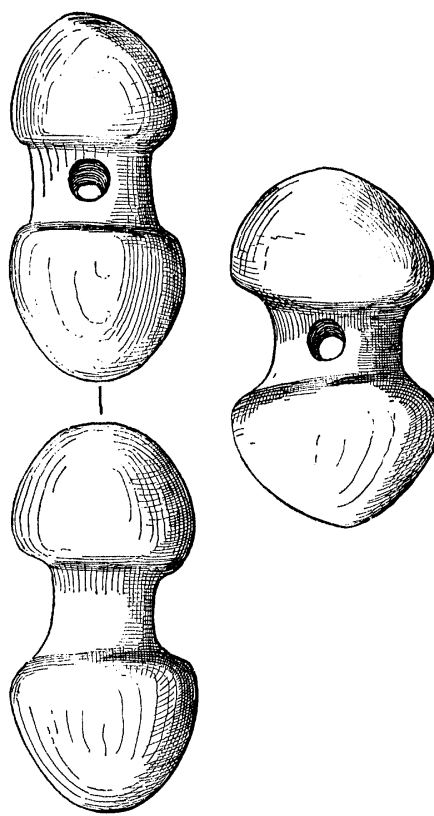

FIG. 8. - SCANDINAVIAN AMBER BEADs. with an entrance gallery. The truth is that the older form does not seem to be copied from any type of stone-hammer, though it presents a close analogy to certain blunt stone implements grooved round the middle, specimens of which have been found in Britain and elsewhere, and to which the name of "sink-stones" has been given. ${ }^{2}$ But in view of the existence of these earlier bone ornaments, which belong to a time when ground and polished implements of stone were perhaps unknown, it hardly seems necessary to derive the early amber forms of Scandinavia from such "sinkstones."

In addition to the above type of bone ornament with its egg-shaped ends, I saw part of another somewhat analogous specimen, of which a representation is given in Fig. 9 . It will be seen that it must have originally consisted of two semi-

spherical bosses, flat below, and linked by a thin perforated neck. The bone in this case also is covered with the converging rows of parallel lines. Half of another example found near the skeletons is preserved in the Geological Museum at Gerioa. ${ }^{3}$

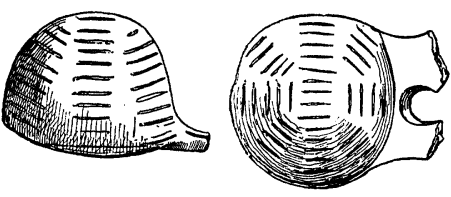

FIG. 9.-BONE ORNAMENT.

This geometrical system of ornamentation seems to be foreign to the decorative system as found on bone and horn objects of

1 This form is flatter, and the central part is cut out more at right angles. An example is given by Neergaard, op. cit., p. 292. These flat types are found in a later type of Cist grave.

${ }^{2}$ In "Liguria Geologica e Preistorica," II, 263, it is figured as if entire ; but this restoration is the work of the artisi. Neither have I seen any like those engraved in "Anthropologie," III, 530, with the flat part complete and the striæ differently arranged. Can this be also due to the draughtsman ?

3 J. Evans, "Ancient Stone Implements of Great Britain," p. 211, see Fig. 159. 
"the Reindeer Period." 1 On the other hand, like the bone ornaments themselves on which it occurs, it presents the closest analogy to a style of decoration very characteristic of the Stone Age in Northern Europe. Dr. Söderberg, who was struck by this, has kindly sketched for me a Danish hanging-pot of Neolithic date, the striations on which show distinct points of resemblance to the last-mentioned bone ornament from the Barma Grande (Fig. 10). The same decorative system is common to a whole series of vessels belonging to the Neolithic Period in North-West Germany and Scandinavia, where it is most frequently found on the lids. In a still more literal guise-zones and columns of parallel lines-this kind of ornament is also found on the Neolithic pottery of East and West Prussia. ${ }^{2}$

The conclusion, then, to which we are led by these converging lines of evidence is that the interments of the Barma Grande and the

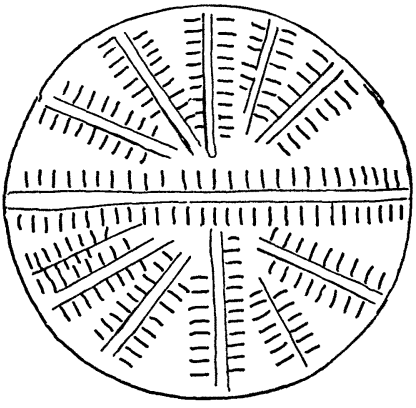

Fia. 10.-BOTtoM OF HANGING VESSEL $\left(\frac{1}{2}\right)$.

[Copenhagen Museum.] other caves of the Balzi Rossi cliffs, though embedded in a Palæolithic stratum are themselves of Neolithic date. On the other hand, however, the entire absence of pottery, of polished implements, of remains of domestic animals, as compared with the Neolithic interments of the Finale Caves further up the same Ligurian coast, is on any showing a most remarkable phenomenon. A greater degree of petrification is also observable in the bone and other objects discovered. In all probability we have here to deal with an earlier Neolithic stratum than any of which we have hitherto possessed authentic records. If the evidence of these Balzi Rossi interments is to count for anything, it must henceforth be recognized that a race representing the essential features of the later population of the polished Stone Age was already settled on the Ligurian shores of the Mediterranean at a time when many of the civilized arts, which have hitherto been considered the original possession of Neolithic Man on his first appearance in Europe, were unknown. It will no longer be allowable to say that these supposed immigrants from Asia brought with them at their first coming certain domestic animals, and had already attained a knowledge of the potter's art, and of the polishing of stone weapons. And, if

1 Rows of parallel lines or long notches are indeed known (e.g., "Reliquiæ Aquitanicæ," B. Pl. XXV), but not arranged in regular converging columns.

2 Cf. Dr. O. Tischler, "Steinzeit in Ostpreussen," p. 4 (Fig. 1), \&c. VOL. XXII. 
this is the case, something at least will have been done towards bridging the gup between the earlier and later Stone Age in Europe. Till such time, however, as remains of extinct animals are found in such association with human interments as to prove their contemporaneity we must still allow for a vast interval of years between the latest remains of the "Reindeer Period"1 and interments, such as those of the Mentone Caves.

The racial characteristics of the skeletons of the Balzi Rossi, ${ }^{2}$ while linking them at one end with the later Neolithic occupants of the Finalese, show that they had essentially the same physical type as the early skeletons found in Cro-Magnon Cave with very similar ornaments of bored shells and teeth. The same features occur again in the skeletons from the Neolithic grotto of the Homme Mort, in Lozère, and in some of the French dolmens, as that of Vignettes. ${ }^{3}$ The type recurs East of the Apennines and in Central Italy, Sicily and Sardinia; and the field of comparison extends to Southern Spain and the Canaries. ${ }^{4}$

The physical connexion with the Dolmen people derives additional interest from the comparisons established between the bone ornaments found with the Barma Grande skeletons and the amber hammer-beads of the Scandinavian Gallery Graves, and the decorative system of the pottery found in the same. It looks as if in the polished Stone Age the Neolithic settlers in the North of Europe had transferred to the new materials, such as amber and earthenware, forms and ornamentation which had already been an ancient possession of a race settled on European soil in still more primitive times.

Two shells found with the Balzi Rossi interments, Pecten maximus $^{5}$ and Cyproca millepunctata ${ }^{6}$ point to Atlantic connexions. In the later Neolithic interments of the Finalese, on the other hand, which may represent the same race in a more advanced stage of development, we see new influences coming in from a very different direction. Some of the shells found with these seem to have been derived from the Southern Mediterranean, ${ }^{7}$ and one, the Mitra oleaces, found by Pro-

1 In Liguria there seems to have been, strictly speaking, no Reindeer Period, as remains of that animal have not been found. But the bones of the Glutton and the primitive Marmot (Arctomys primigenia) found in the Balzi Rossi Caves point to analogous climatic conditions, and implements of the La Mareleine type are well represented.

2 See specially Issel, "Nuove ricerche sulle Caverne ossifere della Liguria."

3 Issel op cit.

4 " Liguria," \&c., 356.

${ }^{5}$ From the Barma dou Cavillou interment; Rivière, op. cit.

${ }^{6}$ Found with the Barma Grande skeletons. See A. V. Jennings, op . cit., p. 276.

7 See especially A. Issel, "Scavi recenti nella Caverna della Arene Candide in Liguria," p. 210 seqq. (Memorie della R. Acc. dei Lincei 1877-1878.) 
fessor Issel in the Caverna delle Arene Candide must have made its way by some primitive line of commerce from the Indian Ocean. ${ }^{1}$

This is not the place to develop in detail the evidence supplied by these later care-burials of the Finalese, the more so as important monographs on this subject are being prepared by two indefatigable local excavators, Padre Amerano of Finalmarina and Padre Morelli of Genoa. The subject, however, is of such importance in relation to the earlier interments of the caves near Mentone, that I may be allowed to give a few impressions derived from such studies as I have myself been able to make of the Finale discoveries. The objects themselves are to be seen partly in the Collegio Ghiglieri at that place, partly in the Geological Museum, and in the private Collections of Don Morelli and of Signor Rossi at Genoa, and a very good example of a Neolithic skeleton with associated relics has been lately procured by Mr. Clarence Bicknell for the local Museum founded by hin in Bordighera.

The racial character presented by the human remains is, as already observed, essentially the same as that of the Balzi Rossi skeletons. We have to deal with the same tall dolichocephalic race with rectangular orbits, a race which still finds its representatives among the hill-folk of Liguria. The mode of burial revealed by these excavations presents, as already noticed, distinct points of similarity to the earlier funeral cult of the Mentone Caves. The provision of red ochre, the perforated shell ornaments, the very posture of the body, and some of the bone instruments found, still betray the earlier tradition, though the pottery and polished axes, the implements of imported jadeite and obsidian, the bones of domesticated animals, the regular cist which protected the remains, all proclaim a higher grade of culture. Among the new forms of instrument here found are certain clay stamps, compared by Professor Issel with the "Pintaderas" with which the ancient Mexicans imprinted coloured patterns on their skins. ${ }^{2}$

Nor is it the imported shells alone that give us a clue to the direction from which the new civilizing influences were being brought to bear on the old indigenous race of this Ligurian coastland. In examining the forms of earthenware vessels

\footnotetext{
1 So, too, Strobel discovered in the "Fondi di Capanne," Meleagrina margaritifera, a shell derived from the Red Sea or Persian Gulf. $C f$. "Bullettino di Paletnologia Italiana," III, p. 56.

2 "Scavi recenti nella Caverna delle Arene Candide in Liguria," p. 130, seqq., and Tav. V. 1, 2. Similar instruments were used by the Guanches of Grande Canary. See Dr. R. Verneau "Las pintaderas de Gran Canaria," Ann. p. la Soc. Española de Hist. Nat. xii, 1883.
} 
discovered, some very remarkable parallels suggest themselyes. A peculiar form of bowl with a kind of cruciform ornament on ts bottom and curves on its side which is one of the most typical objects discovered, is identical with some of the most characteristic of the clay vessels found in the Terremare of the other side of the Apennines, notably that of Castione, near Parma, described by Strobel, where remains of the very baskets were found from which these clay forms seem to have originated. It will be seen from this that the attempt of some Italian archæologists to draw a hard and fast line between the culture revealed in the Terremare of the Po Valley and that of the more Westerly region is hardly borne out by these discoveries in the Finale Caves. It is, indeed, evident that the bulk of the remains in the Finalese Caves belongs to an earlier period than those of the Terremare, and rather represent the antecedent stage of Neolithic and " Eneolithic" culture out of which they grew. It is also true that certain ceramic developments which characterize these latter settlements, such as the semilunar handles, and several types of implements of bronze and bone, have not as yet been found on the Ligurian side. But a stage of culture closely allied to that of the Terremare is unquestionably to be found in the later strata of the Finalese Caves. Certain forms of handle, moreover, occur from which the semilunar type might easily develop itself: the horned handle (ansa a cornetti) has now actually come to light, and, in view of the identity of some of the most characteristic of the ceramic forms as well as of certain types of implements, we may reasonably expect to find the field of comparison enlarged by fresh discoveries. The forms referred to are not, like the earlier types, found in association with skeleton interments, and there is nothing to prove that cremation was not at this time already making good its hold on this side of the Apennines. It is even possible that remains of primitive habitations may be brought to light in the Ligurian coastlands as closely resembling the structure of the pile settlements of Lombardy and the Emilia as the clay vessels found resemble those of Castione and other Transapennine stations.

Other Italian comparisons evoked by these discoveries take us still further afield. The Neolithic remains from the Sardinian Caves display a decided parallelism. Certain forms of vessels like double or reversible cups suggest that we have here the prototypes of the highly developed double or pedestalled cup, found in the early Sicilian cemeteries of Mykênæan Age, on which so much light has recently been thrown by the researches of Dr. Paolo Orsi. In the case of some fragments of primitive painted pottery we have, I venture to believe, a sister 
fabric to the early painted vessels of the Sikel tombs, and to a kindred ware found in the old Iapygian country about Taranto. Nor, when we remember the historic evidence that the Sikels themselves migrated from the Italian mainland and had at one time occupied large tracts of Central Italy as far as Southern Etruria and Liguria itself, is there any $a$ priori reason for doubting these comparisons.

Another favourite thesis of Professor Pigorini and others that the Ligurian Stone Age was prolonged to the time of the Roman Conquest ${ }^{1}$ seems to me to be wholly at variance with the evidence now before us. For, in the Finale Caves, notably that of the Pollera, a progressive culture may be observed in successive layers, and, though metal objects are rare, there is distinct evidence that the deposits continued into the early metal age. The vessels of the Castione type themselves betray contemporaneity of date. Bronze dagger-blades have been found of a type that occurs in the Terremare and a curious cruciform ornament of thin bronze plate, while distantly recailing some of the gold quatre-foils of Mykênæ, presents a somewhat close analogy to the plates of certain types of spiral fibulæ belonging to the late Bronze or earliest Iron Age in Southern Italy. A variety of comparisons lead us to the conclusion that the latest of these interments does not go down much beyond the close of the second Millennium before our era.

If in Roman times the caves were again partially used, either for habitation or interment, the fact ought certainly not to be adduced as a proof that the Liguriau Stone Age goes down to

1 This is repeated in the most unqualified form by Professor L. Pigorini, in one of his most recent publications ("I primitivi abitatori della Valle del Po," Rome, 1892).- " Solo tra le Alpi orientali e su quelle occidentali non penetrava la luce. Cadeva la Repubblica Romana e nel cuore della Liguria eranvi ancora Cavernicoli colle artí e coi costumi della pura età neolitica." Much stress has been laid by certain writers on a passage of Diodôros $\mathrm{V}, 49$, who speaks of some of the Alpine Ligurians as sleeping in caves, which is no more than what many shepherds in this and other parts of Italy do still when tending their summer pastures. But the writers who lav such stress on this, omit some other still more pertinent facts recorded by Diodôros about the Ligurians. He expresses admiration at the industrious way in which they cultivated their rocky soil, and overcame all natural obstacles. He notices that their shields approached the Gallic in character, which indicates a high grade of metallurgic industry. Their brazen shields indeed seem to have so impressed observers that on the strength of them, according to Strabo (lib. iv.) a Greek origin was claimed by some for the Ligurians. Their national armament was at least so effective as to render their services raluable to the Carthaginians and the Sicllian tyrants, who largely employed them as mercenaries along with Etruscans and Campanians. By the end of the first century B.c., when Diodôros wrote, they were giving up their national arms for the Roman. From Strabo (lib. iv.), whose account is probably based on Poseidonios, we learn that they imported oil and wine, but that a certain amount of wine of the quality of the modern Greek retzinata was made in the country. Ligurian tunics and cloaks (saga) were known to commerce and Genoa a thriving market. 
that date. One of the best results obtained in the domain of prehistoric archæology is that there was a constant tendency for civilization at least in North-Western, Central, and South-Eastern Europe, to find a common level, and that, for instance, as Montelius has shown, the difference between the Bronze Age chronology of Italy and Scandinavia is not considerable. ${ }^{1}$ But to suppose that the old population of these Ligurian coastlands, possessed not of rugged mountain ranges only but of valleys of surpassing richness, and ports and suitable landing-places for primitive navigation-living themselves within sight of the Tuscan hills beyond the gulf-should, as far as regards the essentials of culture, have remained over a thousand years brhind the inhabitants of Scandinavian fiords, passes the limits of credibility.

The associated relics discovered in the more recent interments of the Finale Caves shows, on the contrary, that the prehistoric inhabitants of this Ligurian coast possessed a form of culture which must be regarded as a collateral branch of that Italic Class represented by the contemporary dwellers in the Po Valley, offshoots of which were thrown out in other directions as far as Sicily and Sardinia. The Eastern extension of the same primitive civilization, which here touched the Mediterranean shore, may in fact be traced through North Italy and Switzerland-where we see it in the Lake Dwellings-in a closely allied form eastwards to the similar settlements about Laibach in Carniola, to the Danubian Valley, and still further afield through the old Thracian and Illyrian regions of the Balkan Peninsula to Greece on the one hand, and on the other to the North-Western coast of Asia Minor. It is a remarkable fact that owl-like human figures, the counterpart of those discovered by Dr. Schliemann in the Troad,-and at the same time perhaps the nearest existing prototypes of those of Mykênæ,-have come to light in the Finale Caves. ${ }^{2}$

This wide diffusion of kindred forms of culture may well have been the gradual result of the opening up by intertribal barter of primitive lines of commerce, in the case of Liguria no doubt partly maritime, and does not necessarily imply wholesale migration and displacement of the pre-existing European populations. On the contrary, as has been already pointed

$1 C f$. Montelius : "Om Tidsbestämning inom Bronsåldern."

2 Two examples from the collection of Don Morelli have now been published in Prof. Issel's "Liguria Geolog'ca e Preistorica," Tav. xxviii, Figs. 11 and 14. A recent examination of these primitive "idols" has revealed to me the fact that one of them (op. cit. Tav. xxviii, Fig. 14) was painted in the same styce as the early pottery, - a faint rose ground colour with a brown band. 'This affords another and very interesting link to the Mykênæan figures. But the Ligurian e rample is far older. 
out, the comparison that we have been able to institute between the early Neolithic folk whose remains have been brought to light in the Balzi Rossi Caves-the so-called "Man of Mentone" - and the later interments of the Finale group clearly point to continuity of race.

\section{Polynestan Ornament $a$ MYthography ; or $a$ Symbolism of ORIGIN and DESCENT.}

By H. Colley March, M.D., F.S.A.

[WITh PLATES XX-XXIII.]

Eiditions Cited-

Cook's "Voyages," \&c., 1790, six vols.

Ellis's " Polynesian Researches," 1840, four vols.

Gill's "Myths and Songs from the South Pacific," 1876.

"Jottings from the Pacific," 1885.

Grey's "Polynesian Mythology," 1855.

Williams' “ Missionary Enterprise," 1838.

Farmer's “Tonga," \&c., 1855.

Davies" "Dictionary of the Tahitian Dialect," 1857.

Pratt's "Dictionary of the Samoan Language," 1878.

W'. Williams' "Dictionary of the New Zealand Language," 1852.

Stolpe's " Utvecklingsföreteelser i Naturfolkens Ornamentik," published in "Yimer," 1890.

Edge-Partington and Heape's "Ethnographical Album of the Pacific I-lands," 1891.

Martin's "Series of Photographs of New Zealand My thographs," 1890.

Read's "Origin and Sacred Character of certain Ornaments of the South Pacific," 1891.

IN a Paper read by the present writer to the Lancashire and Cheshire and Antiquarian Society, in February, 1889, on "The Meaning of Ornament," it was maintained that "Zoomorphs took their place in the expectant mind by virtue of some symbolic or mythological meaning, and when this was lost, animal forms were reproduced by the artificer with less attention to detail, and only to satisfy a vague desire for something mystical or auspicious."

But one of the principal purposes of that Paper was to show how the animal form passed into ornament under the control and determination of a pre-existent "skeuomorph " or structureform, although different "skeuomorphs" became dominant at different times and among different nations.

It was further noticed that "the effect of the tool was best seen in savage ornamentation where decorative motives had been transferred, for example, to clubs and paddles. The limited power of the stone implement, no less than the grain and hardness of the wood, greatly modified the 'skeuomorphs' 